\title{
Enhancing income and employment on marginal and small farms through dairying in Punjab
}

\author{
Sukhdeep Kaur and Parminder Kaur
}

Received: 25 February 2019 / Accepted: 25 July 2019 / Published online: 27 August 2019

(c) Indian Dairy Association (India) 2019

\begin{abstract}
The study was undertaken to estimate the costs and returns in crop production and dairying on marginal and small farms and to analyse the contribution of dairying in income and employment of selected household farmers in Punjab. Primary data using personal interview method were collected from 90 marginal and small farmers from three districts i..e. Hoshiarpur, Ludhiana and Bathinda representing each of the three agro-climatic zones of the state during 2014-15. The average operational holding on marginal and small farms was 1.59 acres and 3.48 acres respectively. The average number of milch animals kept on these farms were 3.21 and 4.05 respectively. On an average, marginal farmer could receive Rs 39845.00 per acre over cost A1 level while small farmer could fetch Rs 38902.83 per acre over cost A1 level in crop production.. The gross returns from dairying were of the order of Rs. 298095.42 and Rs.362591.61 on the respective categories of farms. The returns over cost A1 in dairying were found to be Rs. 171488.35 and Rs.173068.71 on marginal and small farms respectively. The share of dairying in gross farm family income was found higher on marginal farms $(53.77 \%)$ than that of small farms $(46.92 \%)$ while the share of crop production worked out to be higher on small farms $(35.70$ $\%$ ) as compared to marginal farms $(23.24 \%)$. Further, on an average, marginal farmer employed 64.45 and 135.65 man days in crop production and dairy farming respectively whereas small farmer employed 145.87 and 164.11 man days in crop production and dairy farming respectively. Thus, it can be concluded that dairying plays a vital role the context of rural economy as it
\end{abstract}

Sukhdeep Kaur and Parminder Kaur $(\square)$

Department of Economics and Sociology

Punjab Agricultural University, Ludhiana-141 004, Punjab, India

Email: parminderkaur@pau.edu provides opportunity for supplementary employment and additional income to marginal and small framers. As dairying is emerging as a saviour of marginal and small farmers, development of dairy enterprise need to be given priority for raising the income levels of marginal and small farmers.

Keywords: Costs and returns, Crop production, Dairying, Employment, Income, Marginal and Small farmers

\section{Introduction}

One of the most significant changes in India's agricultural economy over the past three and a half decades has been the rising contribution of livestock sector in the agricultural Gross Domestic Product (AgGDP). The contribution of livestock sector in total GVA and AgGVA has increased to 4.5 percent and 25.80 percent respectively during 2015-16, while on the contrary share of agriculture and allied sectors to the GDP has decreased over the years (GOI, 2017). The contribution of livestock to the total GDP has fluctuated least over the decades as compared to agriculture and allied sectors providing higher degree of livelihood and social security to the livestock keepers in comparison to farmers depending on agriculture alone. The rapid increase in population, sub-division of land holdings and changed family system from joint to nuclear families have made the size of operational holding smaller and smaller. Between 1970-71 and 2010-11, the total number of operational holdings in India increased from 71.01 million to 138.34 million whereas the operational area declined from 162.18 million ha to 159.59 million ha during the same period. The marginal and small farmers account for nearly 85.01 per cent of the total operational holdings in the country, cultivating about 44.58 per cent of the total area (Anonymous 2014). These farmers are embroiled in the vicious cycle of low savings even dissavings, low investment and low returns along with the problem of under nutrition, malnutrition, illiteracy, indebtedness etc. Their standard of living is quite low rather deplorable (Kaur et al 2008).

Punjab is one of the most progressive states of India. Out of 10.58 lakh total holdings in the state, as per the Agricultural Census of 2010-11, the number of marginal and small holdings was 1.64 lakh (15.50\%) and 1.96 lakh $(18.53 \%)$ respectively. It is 
often asserted that small farmers are non viable on their own. Even if farmers cultivate the best possible crops or combination of crops, the return will remain meager. The deepening of economic and ecological crisis and globalization of economy are likely to have adverse impact on these farm categories. Moreover, it is this category of farmers who have a high mortgage debt. The mortgage debt makes their dependence on informal sources greater than other categories of farmers (Shergill 2001). The unbearable debt burden becomes deadly when there is crop failure due to floods, pest-attack, etc. Many of these farmers are facing crisis of viability and their existence as farmers is threatened. The potential of integration of dairy, poultry, piggery, duckery, beekeeping, fishery with dominant crops/cropping systems needs to be exploited to make judicious use of farm inputs, resource management, regular income and year round employment generation on marginal and small land holdings. Dairy farming has been looked upon by the poor as a mean of livelihood, since rearing of milch animals (one or two) offer money, milk, fuel and as a security in emergencies (Ramkumar and Rao 2001). More than an economic activity, dairying empowers the women, reduces the risk of crop failure and acts as a productive asset.

Small milk production system is a typical integration of crop, family labour and household activities. The smallholder dairy is a conversion of waste resources into useful products by utilizing crop by-products and residues and the surplus family labour with little or no opportunity cost which otherwise had gone waste. It provides comparative advantage to the small milk producer to produce milk at lower net cost (total cost- value of dung \& draft animals). The present study was initiated to explore the contribution of dairying to income and employment of marginal and small farmers in Punjab. Specifically the objectives of the study were (1) to study the agro-socio-economic profile of sampled marginal and small farmers in Punjab (2) to estimate the costs and returns in crop and dairying on the selected farms and (3) to analyse the contribution of dairying in income and employment of selected household farmers in the study area.

\section{Materials and Methods}

Multistage stratified random sampling technique was used for selection of sample. In the first stage, three districts of Punjab representing each of the three different agro-climatic zones of state and having relatively higher concentration of marginal and small farmers were selected. Hoshiarpur district was selected to represent the low productivity foothills region known as Kandi region (Zone-I), whereas Ludhiana and Bathinda districts represented the high-productivity Central plain (Zone-II), and South western regions (Zone-III), respectively. In the second stage of sampling, one block from each district was selected. In the third stage, two villages from each chosen block were selected randomly. In the fourth stage of sampling, a complete enumeration of all the farmers in the selected villages having less than or equal to 5 acres of operational holding and possessing at least one milch animal was made. The farmers were categorized as marginal farmers having up to 2.5 acres of operational holding and small farmers having 5.0 acres of operational holding. From each village, 15 marginal and small farmers holding milch animals were selected by following probability proportion to size sampling. Thus, in all 90 marginal and small farmers were selected for the study. Primary data were collected from the sample households for the year 2014-15 by personal interview method using a specially designed and pre-tested schedule. For the interpretation and comparison of costs and returns from crop production and dairying on different sizes of milk producing units and to generate information on other parameters, tabular analysis was carried out. Descriptive statistics were worked out to understand the structure of costs and returns in crop production and milk production on small and marginal dairy farmers in Punjab.

\section{Costs and Income measures used}

Cost $\mathrm{A}_{1}$ included depreciation on fixed capital, all expenditure in cash and kind incurred in production by the owner operator and interest on working capital. Cost $\mathrm{A}_{2}$ was computed by adding rent paid for leased-in-land to Cost $A_{1}$. Interest on value of owned fixed capital (other than land ) was added to Cost $\mathrm{A}_{1}$ for having Cost $B_{1}$. Cost $B_{2}$ was obtained by adding rented value of owned land + rent paid for leased-in-land to Cost B1 Cost $C_{1}$ was computed by adding Imputed value of family labour to Cost $\mathrm{B}_{1}$ while Cost $\mathrm{C}_{2}$ was obtained by adding Imputed value of family labour to Cost $\mathrm{B}_{2}$

Gross farm income was derived by adding together the returns from the sale of main-product and by-products of crops and dairy enterprises on the farm. Off-farm income was calculated by adding income earned from various non-farm sources like service, pension, business, transport, hiring out labour, etc., by the farm family. Gross farm family income was derived by adding the offfarm income to the gross farm income of the farm family. Farm business income was calculated by deducting the operating expenses from the gross farm income of the farm family.

\section{Results and Discussion}

\section{Agro-socio-economic characteristics of marginal and small farmers}

An attempt has been made to document the important socio characteristics of the respondent households, which include age, family size, education status of head of the family, dairy experience, operational size of holding, area under different crops, dairy herd structure and investment pattern. The agro-socio-economic characteristics of the sampled farmers is presented in Table 1.

The perusal of Table reveals that on an average marginal (32.56 $\%$ ) and small farmers (34.04\%) constituted extremely higher number within age group of $45-55$ years. The average family size 
of the marginal and small farmers in Punjab was 4.98 and 4.79 members respectively.

The awareness and knowledge level of the farmers is best judged through their education because better education enables better comprehension of farming technologies and their possible adoption to enhance profitability. Majority of marginal (65.12\%) and small farmers $(65.96 \%)$ had their education level upto matric. It was found that marginal and small farmers constituted extremely higher percentage within group of having experience between 11-20 years in dairying farming. Land operated by marginal and small farmers was 1.59 acres and 3.48 acres respectively. On an average, the total investment on farm machinery was estimated to be Rs.67054.07 in case of marginal farmers and Rs.331376.92 in case of small farmers. The herd strength and the number of milch animals in the household directly affect the economy of milk producers. The total number of animals maintained on marginal and small size category of dairy farm were 4.27 and 5.54 respectively. The number of milch animals maintained on the above said categories was 3.21 and 4.05 respectively. The number of buffaloes varied from 2.44 in marginal herd size category to 2.93 in small herd size category. The number of crossbred cows maintained on marginal and small size category of dairy farms was 0.77 and 1.12 respectively. In overall, the number of wet (in milk) animals was 2.97 and 3.31 on respected categories of farm in the state. Per farm investment on milch animals on marginal farms was Rs.126162.79 (42.02\%) of the total fixed investment on dairying while it was Rs. 188127.66 (41.64\%) on small farms. Similar findings were obtained by Kaur et al, 2008 and Kashish et al, 2017.

\section{Cropping pattern on the sampled farms}

The existing cropping pattern on marginal and small farms in the three zones of Punjab has been presented in Table 2. The overall average gross cropped area with the marginal farm was estimated

Table1 Agro-socio-economic characteristics of the sampled farmers

\begin{tabular}{|c|c|c|c|}
\hline Sr. No. & Particulars & Marginal $(n=43)$ & Small $(n=47)$ \\
\hline \multirow[t]{6}{*}{1.} & \multicolumn{3}{|l|}{ Age of the respondents (years) } \\
\hline & Up to35 & $9(20.93)$ & $10(21.28)$ \\
\hline & $35-45$ & $9(20.93)$ & $12(25.53)$ \\
\hline & $45-55$ & $14(32.56)$ & $16(34.04)$ \\
\hline & Above 55 & $11(25.58)$ & $9(19.15)$ \\
\hline & Total no. of farmers & $43(100)$ & $47(100)$ \\
\hline 2. & Family size & 4.98 & 4.79 \\
\hline \multirow[t]{6}{*}{3.} & \multicolumn{3}{|l|}{ Education of head of family } \\
\hline & Illiterate & 6(13.95) & $5(10.64)$ \\
\hline & Up to Matric & $28(65.12)$ & $31(65.96)$ \\
\hline & Sr. Secondary & $5(11.63)$ & $9(19.15)$ \\
\hline & Graduate and above & $4(9.30)$ & $2(4.25)$ \\
\hline & Total no. of farmers & $43(100)$ & $47(100)$ \\
\hline \multirow[t]{6}{*}{4.} & \multicolumn{3}{|c|}{ Dairy experience of head of the family(years) } \\
\hline & Up to 10 & 13(30.23) & $12(30.23)$ \\
\hline & $11-20$ & 18(41.86) & 19(41.86) \\
\hline & $21-30$ & $10(23.26)$ & $10(23.26)$ \\
\hline & Above 30 & $2(4.65)$ & $6(4.65)$ \\
\hline & Total no. of farmers & 43(100) & $47(100)$ \\
\hline \multirow[t]{4}{*}{5.} & Operational holding (Acres) & 1.59 & 3.48 \\
\hline & Owned land & 1.51 & 3.23 \\
\hline & Leased in land & 0.10 & 0.25 \\
\hline & Leased out land & 0.02 & - \\
\hline 6. & Per farm Investment in machinery (Rs.) & 67054.00 & 331376.92 \\
\hline \multirow[t]{5}{*}{7.} & No. of milch animals & 3.21 & 4.05 \\
\hline & (a) Buffaloes & 2.44 & 2.93 \\
\hline & (b)Crossbred cows & 0.77 & 1.12 \\
\hline & (c) Wet animals & 2.97 & 3.31 \\
\hline & Total no. of animals(SAU) & 4.27 & 5.54 \\
\hline 8. & Value of milch animals & 126162.79 & 188127.66 \\
\hline 9. & \multicolumn{2}{|c|}{ Average milk yield per milch animal (litres/day) 6.75} & 6.50 \\
\hline
\end{tabular}

Figures in parentheses indicate the percentages to their respective totals 


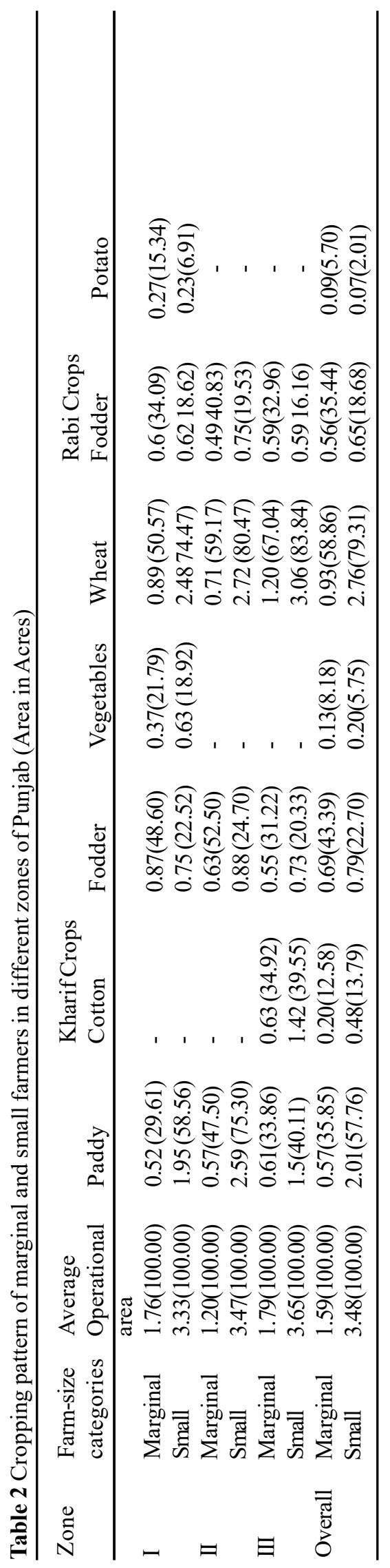

to be 1.59 acres and 3.48 acres for the small farms. The crops grown by the marginal and small farmers in Punjab were paddy, fodder and cotton and vegetables during kharif seasons and wheat, fodder and potato in the rabi season. There was a lot of difference in cropping pattern followed in the three zones. Fodder was major kharif crop grown by marginal farmers in zone-I and zone-II whereas cotton was the major crop in zone-III. In case of small farmers paddy was major crop in all the three zones.

Out of their operational holdings, the marginal farmers in zone-I covered 29.61 per cent, 48.60 per cent and 21.79 per cent of the area under paddy, fodder and vegetable crops respectively. The marginal farmers of zone-II placed 47.50 per cent and 52.50 per cent of their operational area under paddy and fodder crops respectively and whereas the marginal farmers of zone-III covered 33.86 per cent, 34.92 per cent and 31.22 per cent of the operational area under paddy, cotton and fodder, respectively.

Similarly, the corresponding shares of operational area in case of small farmers in zone-I under paddy, fodder and vegetable crops accounted for 58.56 per cent, 22.52 per cent and 18.92 per cent respectively. The small farmers in zone-II operated 75.30 per cent and 24.70 per cent of their operational area under paddy and fodder crops while in zone-III 40.11 per cent, 39.55 per cent and 20.33 per cent of operational area was covered by the small farmers under paddy, cotton and green fodder respectively during kharif season.

During rabi season, wheat crop dominated the cropping pattern and occupied large share in the operational area on both the marginal and small farms in different zones of Punjab during 201415. The marginal farmers of zone-I put 50.57 per cent of their operational area under wheat crop. The corresponding share of operational area in case of marginal farmers of zone-II and zoneIII were 59.17 and 67.04 per cent respectively. Similarly, the small farmers of zone-I placed 74.47 per cent of their operational area under wheat crop. The corresponding shares of operational area in case of small farmers of zone-II and zone-III under wheat were 80.47 per cent and 83.84 per cent respectively. The marginal and small farmers in zone-I placed 15.34 and 6.91 per cent of their operational area under potato crop respectively.

After the area under wheat and paddy crops, fodder crops emerged as the second major crops on both the categories of farms in all the zones of the state. It was due to the fact that dairy farming played a significant role in the household economies of the marginal and small farmers accounting for significant proportion in income and employment. Overall, the marginal farmers operated $35.85,12.58,43.39$ and 8.18 per cent of their operational area under paddy, cotton, fodder and vegetables in kharif season and 58.86, 35.44 and 5.70 per cent of the area under wheat, fodder and potato in rabi season. Similarly, the corresponding share of operational area in case of small farmers under paddy, cotton, fodder and vegetables was 57.76, 13.79, 
22.70 and 5.75 per cent in kharif season whereas the operational area under wheat, fodder and potato was 79.31, 18.68 and 2.01 per cent in rabi season.

\section{Costs and returns in crop production on Marginal and Small farms in Punjab}

Per acre costs and returns in crop production on marginal and small farms in different zones of Punjab is presented in Table 3. In overall situation, the cost A1 worked to be Rs.41163.93 and Rs 40259.56 per acre on marginal and small farms respectively. The cost increased to Rs 56852.74 and Rs 60265.94 per acre on respective categories of farms with the addition of interest on fixed capital and imputed value of family labour to the cost of production. The cost C2 worked out to be Rs 94141.12 per acre on marginal farms and Rs 94648.92 per acre on small farms.

Overall gross returns from crops came to be Rs 81008.93 and Rs 79162.39 per acre on marginal and small farms respectively. On an average, marginal farmer could receive Rs 39845.00 per acre on cost A1 level while an average small farmer could fetch Rs 38902.83 per acre over cost A1 level. The returns over cost B1 and B2 were estimated as Rs 36186.76 and Rs 31505.77 and Rs -1101.60, Rs 2877.21 respectively on the said categories of farms. With the addition of imputed value of family labour i.e. cost $\mathrm{C} 1$, the returns came down to Rs 24176.77 and Rs 18896.47 respectively. The returns over cost C2 turned to be negative i.e. Rs. -13132.19 and Rs -15486.54 on marginal and small farms respectively. Thus, in overall, the marginal and small farmers got nothing for owned land.

The cost of crop production per acre was found to be the lowest in zone-II and the highest in zone-I followed by zone-III due to cultivation of only one crop in one season in zone-I and high costing paddy and cotton crops in zone-I and zone-III respectively. Another reason of higher cost of production in zone-I and zoneIII was higher rental value of owned land due to its higher productivity. Moreover, the use of human labour per acre was also quite high in zone-I and zone-III as compared to zone-II due to some labour intensive operations of paddy, vegetables and cotton crops such as transplanting, harvesting, threshing, irrigation, picking and uprooting of sticks etc.

Per acre gross returns were also worked out to be higher in zoneI and zone-III as compared to zone-II. It might be attributed to the yield and price variation of vegetables, paddy and cotton crops in these zones. The marginal farmers in zone-I were enjoying better returns over cost $\mathrm{C} 1$ followed by marginal farmers in zoneII and zone-III whereas small farmers in zone-II were enjoying better returns over cost $\mathrm{C} 1$ followed by small farmers in zone-III and zone-I. However, the marginal and small farmers in all the zones were non-beneficial at cost B2 and cost C2 level, except marginal farmers in zone-I.

\section{Costs and returns in dairy farming}

Pattern of milk production, consumption and marketed surplus on marginal and small farms in different zones of Punjab is presented in Table 4. The results reveal that out of the total milk production of 25.26 litres per day, the marginal farmers in zone-I retained 5.73 litres $(22.68 \%)$ for household consumption and remaining 19.53 litres $(77.32 \%)$ sold in the market. The marginal farmers in zone-II and zone-III retained 3.79 litres (13.89\%), 4.00 litres $(15.34 \%)$ respectively out of total production of 27.29 litres and 26.07 litres respectively and remaining $23.50(86.11 \%)$ litres and 22.07 (84.66 \%) litres sold in the market. Similarly, the small farmers, in zone-I, zone-II and zone-III retained 5.00 litres (16.93 $\%), 4.75$ litres (14.56\%) and 3.69 litres (12.25\%) respectively out of the total milk production of 29.53 litres, 32.63 litres and 30.13 litres respectively and remaining 24.53 litres (83.07\%), 27.88 (85.44 $\%$ ) and 26.44 litres $(87.75 \%)$ respectively sold in the market.

It is clearly emerged from the table that the total milk production was more on both marginal and small farms of zone-II as compared to that on marginal and small farms in zone-III and zone-I respectively. Because of the reason the marginal and small farmers of zone-II sold comparatively higher percentage of milk produced in the market followed by marginal and small farmers of zone-III and zone-I respectively. Overall, out of the total milk production of 26.18 litres per day, the marginal farmers retained 4.53 litres $(17.30 \%)$ for household consumption and remaining 21.65 litres $(82.70 \%)$ sold in the market. Similarly, the small farmers retained 4.47 litres $(14.52 \%)$ out of the total milk production of 30.79 litres and remaining 26.32 litres $(85.48 \%$ ) sold in the market.

Table 5 presents the costs and returns in dairying on marginal and small farms in different zones of Punjab. In overall situation, the results revealed that the cost on different purchased items as well as depreciation on fixed assets came out to be Rs.126607.07 and Rs.189522.90 on marginal and small farms in the state respectively which ranged between as low as Rs. 1255.45 on interest on working capital to as high as Rs.37709.10 on green fodder on marginal farms while the same ranged between Rs. 1883.07 on interest on working capital to Rs. 44453.97 on green fodder on small farms. By including the interest on fixed capital, it increased to the level of Rs.146534.93 and Rs.219570.77 on marginal and small farms respectively. Family labour was intensively utilized in dairy farming which made an increase of Rs. 37442.51 on marginal and Rs.34605.13 on small farms in the cost of dairy farming. In this way, cost $\mathrm{C} 1$ worked out to be Rs.183977.44 and Rs.254175.86 on marginal and small farms in the state respectively. The gross returns from dairying were of the order of Rs. 298095.42 and Rs.362591.61 on the respective categories of farms. At the level cost A1 i.e. fixed and purchased working resources, the returns were found to be Rs. 171488.35 and Rs.173068.71 on marginal and small farms respectively which declined to the level of Rs.151560.49 and Rs.143020.84 with the inclusion of interest on fixed capital to the cost of dairy farming 
on respective categories of farm. With the addition of family labour use in the cost, the returns pushed down to Rs.114117.97 and Rs. 108415.75 on marginal and small farms respectively. Similar findings were obtained in study conducted by Singh and Joshi, 2008, Brar et al, 2017 and Kashish et al, 2016. The results revealed that gross returns from dairying in zone II were found highest on marginal as well as on small farms which might be due to higher milk production on these farms as compared to other zones i.e. zone I and zone III.

It is evident from the Table 5 that on dairy farming hired human labour was used to the lowest extent, even no use of hired labour was recorded on marginal farms in zone-I and zone-III. Concentrates and mineral mixture were also used more by the famers in zone-II. All this resulted in the highest cost of dairy farming at each level i.e. cost A1, cost B1 and cost $\mathrm{C} 1$ in zone-II followed by zone-III and zone-I. Thus, from the above discussion it can be brought out that dairying plays an important role on marginal and small farms in providing continuous daily cash income along with the use of crop residues \& by products and more use of family labour.

\section{Farm business income from crop production and dairy farming}

Farm business income from crop production and dairy farming together was estimated to be Rs. 242244.03 and Rs. 303038.49 in zone-I, Rs. 222261.45 and Rs. 304342.38 in zone-II, and Rs. 239488.28 and Rs. 318124.95 in zone-III on both categories of

Table 3 Per acre costs and returns structure in crop production on marginal and small farms in different zones of Punjab

\begin{tabular}{|c|c|c|c|c|c|c|c|c|}
\hline$\overline{\text { Particulars }}$ & Zone-I & & Zone-II & & Zone-III & & Overall & \\
\hline Items of Expenditure & Marginal & Small & Marginal & Small & Marginal & Small & Marginal & Small \\
\hline Depreciation on fixed assets & 3806.19 & 10274.28 & 4967.27 & 8436.74 & 5359.13 & 11363.01 & 4689.82 & 10019.37 \\
\hline Seed & 7683.71 & 4907.90 & 3907.44 & 2451.73 & 3752.99 & 3107.88 & 5174.46 & 3458.98 \\
\hline Fertilizers and FYM & 6503.23 & 5350.55 & 5458.92 & 5247.30 & 5304.14 & 5374.57 & 5772.82 & 5323.58 \\
\hline Plant protection measures & 1955.73 & 2176.67 & 2187.02 & 2508.23 & 2467.57 & 2464.56 & 2197.68 & 2387.55 \\
\hline Irrigation charges & 2796.21 & 2672.17 & 2480.06 & 3410.78 & 3148.44 & 3077.91 & 2807.96 & 3061.74 \\
\hline Hired human labour & 9116.00 & 9129.63 & 8883.92 & 9971.18 & 10138.87 & 10582.19 & 9373.47 & 9910.60 \\
\hline Custom hiring services & 7829.65 & 4908.90 & 10041.67 & 3636.53 & 7757.38 & 2654.11 & 8526.31 & 3708.16 \\
\hline Miscellaneous & 1229.16 & 1252.75 & 1389.88 & 1278.82 & 1556.26 & 1562.50 & 1387.99 & 1367.07 \\
\hline Interest on working capital & 1298.98 & 1063.95 & 1202.21 & 997.65 & 1194.40 & 1008.83 & 1233.42 & 1022.62 \\
\hline Cost A1 & 42218.84 & 41736.83 & 40518.40 & 37938.61 & 40679.20 & 41195.56 & 41163.93 & 40259.56 \\
\hline Rent paid for leased-in-land & 1353.20 & 2211.20 & 899.16 & 2520.00 & 4468.00 & 2905.20 & 2219.49 & 2552.58 \\
\hline $\begin{array}{l}\text { Cost A2 (Cost A1+ Rent } \\
\text { paid for leased-in-land) }\end{array}$ & 43572.03 & 43948.03 & 41417.56 & 40458.61 & 45147.20 & 44100.76 & 43383.42 & 42812.14 \\
\hline Interest on fixed capital & 3141.60 & 7639.03 & 4143.75 & 6042.63 & 3726.25 & 8524.66 & 3658.23 & 7397.07 \\
\hline $\begin{array}{l}\text { Cost B1(Cost A1+ Interest } \\
\text { on fixed capital) }\end{array}$ & 45360.44 & 49375.86 & 44662.15 & 43981.24 & 44405.45 & 49720.22 & 44822.16 & 47656.62 \\
\hline $\begin{array}{l}\text { Rental value of owned } \\
\text { land and rent paid for leased- }\end{array}$ & $\begin{array}{l}34000.00 \\
\text { n-land }\end{array}$ & 32000.00 & 38100.00 & 35000.00 & 40000.00 & 36000.00 & 37288.37 & 34382.98 \\
\hline $\begin{array}{l}\text { Cost B2 (Cost B1+ Rental } \\
\text { value of owned } \\
\text { land and rent paid for leased- }\end{array}$ & 79360.44 & 81375.86 & 82762.15 & 78981.24 & 84405.45 & 85720.22 & 82110.53 & 82039.60 \\
\hline $\begin{array}{l}\text { Imputed value of Family } \\
\text { labour }\end{array}$ & 13875.00 & 14925.22 & 10685.00 & 11218.44 & 11400.00 & 11829.04 & 12030.58 & 12609.32 \\
\hline $\begin{array}{l}\text { Cost } \mathrm{C} 1 \text { (Cost B1 + } \\
\text { Family labour) }\end{array}$ & 59235.44 & 64301.09 & 55347.15 & 55199.68 & 55805.45 & 61549.26 & 56852.74 & 60265.94 \\
\hline $\begin{array}{l}\text { Cost } \mathrm{C} 2 \text { (Cost B2 + } \\
\text { Family labour) } \\
\text { Returns }\end{array}$ & 93235.44 & 96301.09 & 93447.15 & 90199.68 & 95805.45 & 97549.26 & 94141.12 & 94648.92 \\
\hline Gross returns & 94210.23 & 80820.57 & 79176.48 & 77991.98 & 68697.12 & 78778.25 & 81008.93 & 79162.39 \\
\hline Returns over cost A1 & 51991.40 & 39083.74 & 38658.08 & 40053.37 & 28017.92 & 37582.69 & 39845.00 & 38902.83 \\
\hline Returns over cost A2 & 50638.20 & 36872.54 & 37758.93 & 37533.37 & 23549.92 & 34677.49 & 37625.51 & 36350.25 \\
\hline Returns over cost B1 & 48849.80 & 31444.70 & 34514.33 & 34010.75 & 24291.67 & 29058.03 & 36186.76 & 31505.77 \\
\hline Returns over cost B2 & 14849.80 & -555.29 & -3585.67 & -989.26 & -5708.33 & -6941.97 & -1101.60 & -2877.21 \\
\hline Returns over cost $\mathrm{C} 1$ & 34947.80 & 16519.47 & 23829.33 & 22792.31 & 12891.67 & 17228.99 & 24176.77 & 18896.47 \\
\hline Returns over cost $\mathrm{C} 2$ & 974.80 & -15480.53 & -14270.67 & -12207.69 & -27108.33 & -18771.01 & -13132.19 & -15486.54 \\
\hline
\end{tabular}


Table 4 Pattern of milk production, consumption and marketed surplus on marginal and small farms in different zones of Punjab (2014-15)

(Litres/ day)

\begin{tabular}{llllc}
\hline Zone & Farm size & Production & $\begin{array}{l}\text { Home } \\
\text { Consumption }\end{array}$ & $\begin{array}{c}\text { Marketed } \\
\text { Surplus }\end{array}$ \\
& Categories & & $5.73(22.68)$ & $19.53(77.32)$ \\
I & Marginal & $25.26(100.00)$ & $24.53(83.07)$ \\
II & Small & $29.53(100.00)$ & $5.00(16.93)$ & $23.50(86.11)$ \\
& Marginal & $27.29(100.00)$ & $3.79(13.89)$ & $27.88(85.44)$ \\
III & Small & $32.63(100.00)$ & $4.75(14.56)$ & $22.07(84.66)$ \\
& Marginal & $26.07(100.00)$ & $4.00(15.34)$ & $26.44(87.75)$ \\
Overall & Small & $30.13(100.00)$ & $3.69(12.25)$ & $21.65(82.70)$ \\
& Marginal & $26.18(100.00)$ & $4.53(17.30)$ & $26.32(85.48)$ \\
\hline
\end{tabular}

Figures in parentheses indicate the percentages to total milk production

Table 5 Costs and return structure in dairy farming on marginal and small farms in different zones of Punjab (2014-15)

\begin{tabular}{|c|c|c|c|c|c|c|c|c|}
\hline \multirow{2}{*}{ Particulars } & \multicolumn{2}{|l|}{ ZONE-I } & \multicolumn{2}{|l|}{ ZONE-II } & \multicolumn{2}{|l|}{ ZONE-III } & \multicolumn{2}{|l|}{ Overall } \\
\hline & Marginal & Small & Marginal & Small & Marginal & Small & Marginal & Small \\
\hline$\overline{\text { Cost Items }}$ & & & & & & & & \\
\hline $\begin{array}{l}\text { Depreciation } \\
\text { on fixed assets }\end{array}$ & 16833.34 & 23403.33 & 17251.08 & 30440.63 & 19205.37 & 24680.3 & 17741.64 & 26233.72 \\
\hline Green fodder & 34985.25 & 39168.15 & 40266.80 & 53012.60 & 38069.50 & 40850.80 & 37709.10 & 44453.97 \\
\hline Dry fodder & 21900.00 & 31550.60 & 22465.75 & 42467.75 & 21206.50 & 34828.30 & 21858.41 & 36382.89 \\
\hline Concentrates & 34065.45 & 41730.45 & 34999.85 & 49961.20 & 32850.00 & 37981.90 & 33973.95 & 43256.31 \\
\hline Mineral mixture & 3504.00 & 3894.55 & 4171.95 & 7208.75 & 3755.85 & 4015.00 & 3803.47 & 5063.79 \\
\hline Veterinary services & 2861.60 & 4073.40 & 2518.50 & 3555.10 & 2478.35 & 2193.65 & 2625.11 & 3257.04 \\
\hline Hired human labour & 0.00 & 26765.45 & 23465.85 & 30415.45 & 0.00 & 29656.25 & 7640.04 & 21304.17 \\
\hline $\begin{array}{l}\text { Interest on } \\
\text { working capital }\end{array}$ & 1135.36 & 1717.13 & 1492.04 & 2177.24 & 1147.54 & 1744.47 & 1255.45 & 1883.07 \\
\hline Cost A1 & 115285.00 & 172303.06 & 146631.82 & 219238.72 & 118713.11 & 175950.67 & 126607.07 & 189522.90 \\
\hline $\begin{array}{l}\text { Interest on fixed } \\
\text { Capital }\end{array}$ & 18396.93 & 26808.13 & 20514.50 & 35004.38 & 20981.50 & 28128.63 & 19927.86 & 30047.87 \\
\hline Cost B1 & 133681.93 & 199111.19 & 167146.32 & 254243.10 & 139694.61 & 204079.30 & 146534.93 & 219570.77 \\
\hline $\begin{array}{l}\text { Imputed value of } \\
\text { family labour }\end{array}$ & 37212.00 & 32679.00 & 36600 & 35856.00 & 38532.00 & 35160.00 & 37442.51 & 34605.13 \\
\hline $\begin{array}{l}\text { Cost C1 } \\
\text { Returns }\end{array}$ & 170893.93 & 231790.19 & 203746.32 & 290099.00 & 178226.61 & 239239.30 & 183977.44 & 254175.86 \\
\hline Gross returns & 266024.17 & 345192.7 & 322503.57 & 384595.90 & 308049.31 & 356898.80 & 298095.42 & 362591.61 \\
\hline Returns over cost A1 & 150739.17 & 172889.64 & 175871.75 & 165357.18 & 189336.20 & 180948.13 & 171488.35 & 173068.71 \\
\hline Returns over cost $\mathrm{B} 1$ & 1132342.24 & 146081.51 & 155357.25 & 130352.80 & 168354.70 & 152819.50 & 151560.49 & 143020.84 \\
\hline Returns over cost $\mathrm{C} 1$ & 195130.24 & 113402.51 & 118757.25 & 94496.90 & 129822.70 & 117659.50 & 114117.97 & 108415.75 \\
\hline
\end{tabular}

Table 6 Farm business income from crop production and dairy farming on marginal and small farms in different zones of Punjab

(Rs/farm/annum)

\begin{tabular}{llllllllc}
\hline $\begin{array}{l}\text { S. No.Source } \\
\text { of income }\end{array}$ & Zone-I & Marginal & Small & Mone-II & \multicolumn{3}{c}{ Zone-III } & Overall \\
\hline (I) Crops & 91504.86 & 130148.85 & 46389.70 & 138985.20 & 50152.08 & 137176.82 & 63352.51 & Small \\
(II) Dairy & 150739.17 & 172889.64 & 175871.75 & 165357.18 & 189336.20 & 180948.13 & 171488.35 & 173068.71 \\
$\quad$ Total (I+II) & 242244.03 & 303038.49 & 222261.45 & 304342.38 & 239488.28 & 318124.95 & 234840.86 & 271245.85 \\
\hline
\end{tabular}

farms (Table 6). Overall, the total farm business income came out be Rs. 234840.86 and Rs. 271245.85 on marginal and small farms respectively. Kaur et al, 2008 reported the similar results.
In case of marginal farmers the farm business income in crop production came out to be highest in zone-I followed by zone-III and zone-II and in dairy farming it came out to be highest in zone- 
III followed by zone-II and zone-I respectively. Similarly, in case of small farmers the corresponding returns came out to be the highest in zone-II followed by zone-III and zone-I in crop farming and it came out to be highest in zone-III followed by zone-I and zone-II respectively in dairy farming. Farm business income found to be the highest in dairy farming as compared to crop production on both categories of farmers.

\section{Gross farm family income on marginal and small farms}

The gross farm family income from different farm and non-farm sources on marginal and small farms in different zones of Punjab is shown in Table 7. The gross farm family income from all the sources was worked out to be the highest of the order of Rs.583193.87 on marginal farms in zone-II followed by Rs.546700.88 in zone-I and Rs.533802.82 in zone-III whereas in case of small farms it was highest of the order of Rs.792458.61 in zone-I followed by Rs.773103.09 in zone-II and Rs.754001.93 in zone-III respectively. The analysis further revealed that the share of dairying in gross farm income was the highest on marginal farms in all the zones i.e. 57.71, 55.30 and 48.66 per cent in zoneIII, zone-II and zone-I respectively while the share of crop production came to be the highest on small farms in zone-III $(38.14 \%)$ and zone-II (35.01\%). In zone-II, again the share of dairying on small farms was found to be the highest of the order of 49.75 per cent. This showed that in zone-II, in general and on marginal farms in all the zones, dairy occupied the most significant place in generating farm family income.

The gross farm income from crops and dairying of marginal farmers in zone-III was 84.55 per cent which was higher than that of marginal farmers in zone-I (78.99\%) and zone-II (71.59\%) respectively. Similarly, the gross farm income of small farmers in zone-III was 85.47 per cent which was higher than that of small farmers in zone-II $(84.75 \%)$ and zone-I $(77.52 \%)$ respectively. This may be attributed to the higher value of productivity of different crops and dairying in zone-III and zone-I as compared to zone-II. However, the income from off-farm sources, such as service, pension, sale, remittances, hiring out of machinery and labour services, etc was the highest in zone-II (28.41\%) followed by zone-I (21.01\%) and zone-III (19.26\%) while in case of small farmers the respective share was highest in zone-I $(22.48 \%)$ followed by zone-II (15.25\%) and zone-III (14.53\%) respectively. In overall situation, it was evident from table that the gross farm family income from all the sources was the highest of the order of Rs 772777.86 on small farms followed by Rs 554382.95 on marginal farms. The results were in consonance with the findings of the study conducted by Singh and Joshi, (2008). The share of

Table 7 Gross farm family income from different sources of marginal and small farmers in different zones of Punjab

(Rs./farm family/annum)

\begin{tabular}{llllllllc}
\hline $\begin{array}{l}\text { Source of } \\
\text { income }\end{array}$ & Zone-I & \multicolumn{3}{l}{ Zone-II } & \multicolumn{3}{c}{ Zone-III } & Overall \\
\hline Marginal & Small & Marginal & Small & Marginal & Small & Marginal & Small \\
\hline Crops & 165810.01 & 269132.49 & 95011.78 & 270632.19 & 122967.85 & 287540.63 & 128810.81 & 275909.63 \\
Dairy & $(30.33)$ & $(33.96)$ & $(16.29)$ & $(35.01)$ & $(23.04)$ & $(38.14)$ & $(23.24)$ & $(35.70)$ \\
& 266024.17 & 345192.70 & 322503.57 & 384595.90 & 308049.31 & 356898.80 & 298095.42 & 362591.61 \\
Gross & $(48.66)$ & $(43.56)$ & $(55.30)$ & $(49.75)$ & $(57.71)$ & $(47.33)$ & $(53.77)$ & $(46.92)$ \\
farm Income & 431834.18 & 614325.19 & 417515.35 & 655228.09 & 431017.16 & 644439.43 & 426906.23 & 638501.24 \\
Off- & $(78.99)$ & $(77.52)$ & $(71.59)$ & $(84.75)$ & $(84.55)$ & $(85.47)$ & $(77.01)$ & $(82.62)$ \\
farm income & 114866.70 & 178133.42 & 165678.52 & 117875 & 102785.66 & 109562.50 & 127476.72 & 134276.62 \\
Gross farm & $(21.01)$ & $(22.48)$ & $(28.41)$ & $(15.25)$ & $(19.26)$ & $(14.53)$ & $(22.99)$ & $(17.38)$ \\
family income & 546700.88 & 792458.61 & 583193.87 & 773103.09 & 533802.82 & 754001.93 & 554382.95 & 772777.86 \\
\hline
\end{tabular}

Figures in parentheses indicate the percentages to gross farm family income.

Table 8 Human labour employment in crop production and dairy farming on marginal and small farms in different zones of Punjab (Average mandays/farm/annum)

\begin{tabular}{lllc}
\hline Zone & $\begin{array}{l}\text { Farm-size } \\
\text { Categories }\end{array}$ & $\begin{array}{l}\text { Crop production } \\
\text { (Total mandays) }\end{array}$ & $\begin{array}{c}\text { Dairy farming } \\
\text { (Total mandays) }\end{array}$ \\
\hline I & Marginal & 81.40 & 124.04 \\
& Small & 165.67 & 160.49 \\
II & Marginal & 42.74 & 155.31 \\
& Small & 129.76 & 174.73 \\
III & Marginal & 68.02 & 128.44 \\
& Small & 143.92 & 156.89 \\
Overall & Marginal & 64.45 & 135.65 \\
& Small & 145.87 & 164.11 \\
\hline
\end{tabular}


dairying in gross farm income was higher on marginal farms $(53.77 \%)$ than small farms $(46.92 \%)$ while the share of crop production worked out to be higher on small farms $(35.70 \%)$ as compared to marginal farms $(23.24 \%)$. The gross farm income of small farmer was 82.62 per cent which was higher than that of marginal farmers $(77.01 \%)$. However, the income from off-farm sources was higher on marginal farms $(22.99 \%)$ than small farms $(17.38 \%)$. Thus it can be concluded from the above discussion that with the increase in the farm size, the relative share of crops in the total earning found increased and that of dairying decreased. Dairy farming played an important role in fetching the higher earning on marginal farms which might be due to excessive availability of family labour on these farms.

\section{Human labour employment in crop production and dairy farming}

The pattern of human labour employment in crop production and dairy farming on marginal and small farms in different zones of Punjab is presented in Table 8 . The results revealed that on an average marginal farmer employed 81.40 and 124.04 man days in zone-I, 42.74 and 155.31 man days in zone-II and 68.02 and 128.44 zone-III in crop production and dairy farming respectively whereas small farmer employed 165.67 and 160.49 man days in zone-I, 129.76 and 174.73 in zone-II and 143.92 and 156.89 man days in crop production and dairy farming respectively. In overall situation, on an average, marginal farmer employed 64.45 and 135.65 man days in crop production and dairy farming respectively whereas small farmer employed 145.87 and 164.11 man days in crop production and dairy farming respectively. It was observed that dairy farming played significant role by providing higher human labour employment than crop production on both marginal and small farms.

\section{Conclusions}

Thus, it can be concluded that dairying plays a vital role the context of rural economy as it provides opportunity for supplementary employment and additional income to marginal and small framers. The results brought out that the share of dairy in the farm business income of marginal and small farmers was 73.02 percent and 68.02 percent respectively whereas the share of dairy in gross farm family income was estimated to be 53.77 percent and 46.92 percent respectively on the said categories of farms. Dairy farming played a significant role by providing higher labour employment than crop production on both marginal and small farms. As dairying is emerging as a saviour of marginal and small farmers, development of dairy enterprise needs to be given priority for raising the income levels of marginal and small farms.

\section{References}

Anonymous (2014) Agriculture Census Division, Department of Agriculture and Cooperation, Ministry of Agriculture, Government of India, New Delhi

Brar RS, Kaur I, Singh VP, Chopra S (2017) Comparative profitability of small and medium sized dairy farmers in Punjab. Indian J Econ Dev 13: $143-152$

Government of India (2017) Basic Animal Husbandry and Fisheries Statistics, Department of Animal Husbandry, Dairying and Fisheries, Ministry of Agriculture, New Delhi

Kashish, Kaur M, Sekhon M K, Dhawan V (2017) Impact of dairying on income and income distribution of small holder dairy farmers in Punjab. Ind J Dairy Sci 70:781-788

Kashish, Kaur M, Sekhon MK, Dhawan V (2016) Economic analysis of milk production among small holder dairy farmers in Punjab: A case study of Amritsar district. Indian J Econ Dev 12: 335-340

Kaur P, Bhullar AS, Singh M, Kaur I (2008) Growing importance of dairy in the economy of the marginal and small farmers in Punjab. J Agril Dev Policy 18: 36-46

Ramkumar S, Rao SVN (2001) Cattle rearing as a livelihood activity of the landless in Pondicherry. In: Ramkumar S, Garforth C, Rao S N V and Waldie K (eds) Landless Livestock Farming: Problems and Prospects. Rajiv Gandhi College of Veterinary and Animal Services, Pondicherry.pp 53-73

Shergill H S (2001) Small farmers indebtedness in Punjab. Pol Econ J India 10: $27-32$

Singh M, Joshi AS (2008) Economic analysis of crop production and dairy farming on marginal and small farms in Punjab. Agri Econ Res Rev 21: $251-257$ 